\title{
Faces, Close-ups and Choreography: A Deleuzian Critique of So You Think You Can Dance
}

\author{
Sherril Dodds and Colleen Hooper
}

\section{Facial Choreography and the Choreographic Interface}

In everyday life the face occupies a central position within human expression and social interaction: its features are perceived to present a unique identity, and we breathe, consume and communicate through our faces. ${ }^{1}$ Across film and television, the camera has long been fascinated with the face through the framing device of the close-up. Film scholar Paul Coates asserts that the screen operates as a mask between a distant spectator and a face situated within a complex matrix of spatial and temporal coordinates. ${ }^{2}$ In dance, too, the face plays an important role, in that its expressive capacities are composed according to a range of performance styles and genres. The same applies to screendance, although in this instance the face is subject to a "double choreography." The screendance face both displays the codes and conventions of the particular dance idiom, and also the compositional modalities of camera work and editing, which re-choreograph faces across new vectors of space and time. In this article, we explore two ideas as a means to examine the "screendance face." First we introduce the notion of "facial choreography" to reflect on how the screen apparatus produces representations of dancing faces informed by aesthetic and social values. Secondly, we develop the concept of a "choreographic interface," which we conceive as an intertextual site of meaning whereby a dancing face both references and enters into a dynamic exchange with other faces. While these two concepts could be applied to any screendance face, to elucidate these ideas in motion, we turn to a specific screendance case study.

A quick trawl through the archive of dance routines featured on the popular reality television dance competition So You Think You Can Dance reveals a proclivity for dance styles that deploy dramatic, spectacular, and emotive modes of facial expression. ${ }^{3}$ Across solos, duets and group routines, viewers witness passionate contemporary dance numbers that convey themes of love and loss; Latin American ballroom sequences that signal tempestuous and sexually-charged exchanges; and Broadway comedy routines replete with huge grins, faux confusion, and cheeky winks. We therefore turn to a single audition clip from So You Think You Can Dance, which features Brian Henry, a 22-year old African American man from Brooklyn, New York, who specializes in krumping. ${ }^{4}$ The competition narrative that underpins So You Think You Can Dance already offers rich opportunity for dramatic facial expression, but krumping further engages intense and exaggerated facial gesticulations within its vernacular performance style. 
Although a small body of researchers has briefly examined facial expression within live performance disciplines, ${ }^{5}$ dance scholar Erin Brannigan represents one of the few to consider the face within the field of screendance practice. ${ }^{6}$ Brannigan's work centers on "dance film," and the pertinence of her research here lies in her concept of "micro-choreographies." Recalling film theorist Béla Balàzs, who makes claim for the close-up's capacity to magnify dramatic expression, Brannigan describes how subtle facial movements transform into micro-choreographies within the context of dance film. Although we focus here on the television medium, the "small screen"8 similarly constructs intimate images of localized facial motion rooted in danced expressions and social interactions, both of which serve to "choreograph" meaning within reality television dance shows. Brannigan employs the seminal work of philosophers Gilles Deleuze and Felix Guattari in relation to concepts of facial expression, which we also call upon as the primary theoretical lens for this study. ${ }^{9}$ Yet whereas Brannigan offers a reading of dance film that resists the hierarchical organization of the body, since the face does not serve a central purpose in the "contemporary dance" idiom that informs dance film, we commit to a close analysis of the face as articulated through the choreographic framework of reality television dance shows, in which spectacular facial performances are key.

Deleuze and Guattari have devoted considerable thought to the human face from their perspective of post-structuralist philosophy. In A Thousand Plateaus, they conceive of the face through the semiotic lens of a "white wall" of signifiance and a "black hole" of subjectification. ${ }^{10}$ In a somewhat bleak, anti-humanist vision, they describe this face as a white surface of inscription that is forever deterritorialized from the black hole of subjectivity, a consciousness that can never be accessed or articulated. The construction of this face arises through an "abstract machine of faciality (visagéité),"11 which dance scholar Andre Lepecki interprets as an assemblage of concrete ideas, signs, and phenomena. ${ }^{12}$ The abstract facial machine thus produces legible messages that resist ambiguity, polyvocality, and heterogeneity. Hence the face can only be meaningful through the semiotic coding of the facial machine. As Deleuze and Guattari state, faciality "carries out the prior gridding that makes it possible for the signifying elements to become discernible, and for the subjective choices to be implemented." ${ }^{\prime 13}$

In Cinema 1: The Movement Image, Deleuze usefully draws attention to the face and motion. ${ }^{14}$ Deleuze envisions film as a "machine assemblage of movementimages"15 in which the "movement-image" is comprised of "perception-images, action-images and affection-images." ${ }^{16}$ The affection-image serves as prime interest here in that Deleuze characterizes it through the close-up of the face, which he portrays as a "pure affect," deterritorialized in time and space. Film theorist Richard Rushton explains pure affect in the sense that a sad face does not represent a sad person, but rather the face is sadness. ${ }^{17}$ For Deleuze, the face consists of two poles: the reflective face, which is a unified surface of "pure quality" that is rendered immobile and receptive; and the intensive face, which constitutes an experiencing face that 
conveys a series of expressions that break free from its outline and cross thresholds, which might bring about new moods, emotions, or interactions.

Deleuze and Guattari's conceptions of the face provide a rich analytical tool for our study of So You Think You Can Dance. First, in reference to "facial choreography," we call upon Deleuze and Guattari's concept of faciality to illustrate how the reality television "machine" choreographs the facial expression of Brian Henry to ensure his legibility as an African-American krumper. Secondly, we employ Deleuze's idea of the "reflective" and "intensive" face in reference to the montage of competitor, judge, and spectator interactions, specifically though the close-up. This dynamic framework of exchange, we argue, constitutes a "choreographic interface"; while Henry's intensive face provides opportunity to critique the reality television format, his reflective face enables the construction of pedagogic, aesthetic, and performative values that attempt to regulate social and cultural norms into the viewing experience. Before we move on to this analysis, however, we will contextualize krumping as a dance practice.

\section{Krumping from Street to Screen}

In a recent essay, ethnomusicologist Christina Zanfanga traces how krumping evolved from "clowning," an African American vernacular dance developed by Thomas "Tommy the Clown" Johnson in South Central Los Angeles. ${ }^{18}$ Located in a community that had witnessed the social and racial turbulence of the Rodney King riots in 1992, Johnson developed clowning as a form of entertainment for children's birthday parties. ${ }^{19}$ The dance drew on a combination of hip hop funk styles, Jamaican dancehall, and stripper dancing, but began to shift in tandem with its environment. ${ }^{20}$ As young people became subject to constrictive regulations by the Los Angeles Police Department, which sought to penalize them for minor noise and conduct violations, dancers responded by transformed clowning into a "harder, more aggressive and personal solo style called krumping." ${ }^{21}$ Characterized by sharp chest thrusts, rapid arm gestures, and syncopated isolations that course through the body, krump dancers frequently bare their teeth, purse their lips, stick out their tongues, and lip-synch words while they dance. These micro-choreographies of the face offer a compelling example for the purposes of this article.

The legacy of social and economic disenfranchisement and pent-up frustration intimated above has therefore come to be associated with krumping, and David LaChappelle's film documentary Rize (2005) clearly plays to this connection. ${ }^{22}$ As such, considering Rize alongside So You Think You Can Dance enables us to view the facial choreographies presented within the documentary form as part of the choreographic interface that we employ to read Brian Henry's krumping audition. Although Rize is a documentary film and So You Think You Can Dance is a reality television series, both fabricate highly mediated representations of reality. The film closely follows the historical narrative outlined by Zanfanga with opening footage of burning buildings from the 1965 LA race riots and the 1992 Rodney King riots, and the first part of the 
film focuses on Tommy the Clown's redemptive passage from drug dealer to dancer within some of the most rundown neighborhoods of the LA suburbs. As the film begins to focus on krumping, the colorful clown costumes and mask-like painted clown faces disappear in place of a more aggressive and agitated style of dance that features intense and mobile facial expression.

Set around shots of dilapidated buildings, battered cars and a dirty old mattress on the sidewalk, the camera cuts to headshots of krumpers who reflect on their lived experience: "we're from the inner city, or what you would call the ghetto"; "in better neighborhoods they have performing arts schools ... there's nothing like that available to you when you live where we live"; "what we are, are oppressed." These statements are also intercut with groups of krumpers dancing in basketball courts and other street locations to edgy, urban hip hop tracks, such as Get Krumped by Lil C and Beastly by Flii Stylz. The dancers jerk their torsos and lash out their arms in rapid, quick-fire motion, often pushing, grabbing and shoving at other bodies in the tight krumping circle. Their faces signal anger, rage, and pent-up emotion with gritted teeth, furrowed brows, and flashing eyes. As the film follows the krumpers, ideas concerning sexuality, violence, and religion are rooted into these dancing bodies.

In a scene that explains the "stripper dance," a feature of both clowning and krumping, a series of shots display sweaty bodies consisting of naked male torsos and women dressed in bra tops against a bright pink wall smeared with dirt or mold. The camera cuts between rear images of their buttocks shaking and pelvises twerking, and frontal images that display puckered lips, breathy exhalations and eyes shut as if in private ecstasy. Although the dancers themselves do not make links between the movement and sexuality, the composition of the shots clearly invoke ideas of the erotic. Throughout the film, the audience is reminded that these African American dancers are situated within a social landscape of violence and crime. In one sequence of shots, dancer Lil C describes how his father committed suicide, Tight Eyez details being shot by a family member, and Baby Tight Eyez relays stories of his mother's drug abuse. Yet this "social reality" is intercut with glossy images of a small circle of krumpers, with oiled black skin, dancing against a vivid blue sky. Although their intense, thrusting movement and aggressive facial gesticulations echo ideas expressed earlier in the film-that krumping offers a way for them to channel their anger through this "ghetto ballet" - the tight framing of the muscular black bodies against a pulsating urban hip hop beat recalls the commodified dancing images of commercial music video. Indeed, film critic Chris Ayres suggests that director David LaChapelle "ends up glamorizing the violence," ${ }^{23}$ and film scholar Belinda Smaill identifies how the film is "oriented towards presenting the pleasure of the spectacle of krumping." 24

The documentary narrative of Rize builds towards the Battle Zone, a dance competition organized by Tommy the Clown, which pits the clowns against the krumpers. The placement of dancing bodies within a competition framework offers a clear link to the competition narrative of So You Think You Can Dance. As the film moves to a close, however, it begins to signal the links between krumping and 
religion. The need for spiritual comfort arises through the shared suffering of this community as several scenes focus on the random shooting of a young krumper, Quinesha Dunford. Psychologist Nicole Monteiro suggests that "krump" forms an acronym for "Kingdom Radically Uplifted Mighty Praise," 25 and Zanfanga describes how "many of the dancers proclaim that they "get krump for Christ." ${ }^{26}$ Yet the film ends with three of the dancers krumping on a stretch of urban wasteland against a bright blue sky, and the gratuitous slow motion shots dwell on oiled "six-packs" and bouncing breasts. As we will show, these competing discourses of sexuality, aggression, and religion engendered in Rize also feed into the construction of krumping in So You Think You Can Dance.

\section{Close-up Pedagogies of Krumping}

The clip we focus on introduces Brian Henry at one of the regional auditions, which typically attract dozens of aspiring dancers who hope to be selected for the "choreography round" of the competition. ${ }^{27}$ Dance scholar Kate Elswit usefully formulates the notion of "extended choreography" to explain how reality television employs not only the danced routine, but also the introductory shots and the judges' feedback as a contextualizing narrative that serves to characterize the dancers, as well as to position spectators within a desired viewing experience. ${ }^{28}$ The idea of an extended choreography allows us to consider the motion, composition, and editing of Henry's face throughout the entire audition as a form of "facial choreography," and the framed interactions between Henry, the judges, and the live studio audience as a "choreographic interface." We commence with the pre-audition scene, which introduces Henry prior to meeting the judges.

Framed in a mid-shot against a red brick wall, Henry vigorously thrusts his chest back and forth as his muscular arms drop and cross in front of him and, with eyebrows contorted into a frowning scowl, he appears to emit a silent growl. Dressed in typical street wear of a backwards baseball cap and red t-shirt, with "Brooklyn New York" emblazoned across the front, the familiar So You Think You Can Dance theme music, a mid-tempo guitar track heavy on synthesizers, plays in the background. For a moment, his facial expression appears ambiguous as the shot cuts to a close-up in which he playfully sends a "wave" along each eyebrow, disconcertingly chews on an imaginary object, and aggressively bites toward the camera while snatching out with his hand. In Deleuzian terms, we might suggest that the shot operates as "pure affect" in that Henry's face, dislocated from the centering coordinates of time and space, does not represent but is play, intimidation, and aggression. ${ }^{29}$ In these few fleeting moments, Henry's confusing assemblage of facial expressions disorients the spectator, but quickly, the semiotic principles of Deleuze and Guattari's "facial machine" come into play in the form of the codes and conventions of reality television. ${ }^{30}$ One such semiotic code is the familiar voiceover of host Cat Deeley, who enthusiastically chimes, "Brian Henry is ready to show off what he's learned-on the streets!" 
Both Elswit and cultural theorist Guy Redden argue that reality television talent shows engage a form of pedagogy that educates its audiences about performance standards and behaviors. ${ }^{31}$ Media scholar Su Holmes, meanwhile, suggests that the close-up acts as a rhetorical device in that it "offers the impression that we are getting close to the person, something then intensified by the particular formal and aesthetic construction of reality TV." ${ }^{22}$ In this brief introductory scene, a series of close-ups swiftly constructs a pedagogy of krumping and a characterization of Brian Henry that makes both the dance and the dancer legible for the television spectator. The importance of facial choreography in krumping is immediately established and continues throughout the pre-audition scene: Henry crosses his eyes, sticks out his tongue, snarls aggressively, and strains his jaw and mouth.

Yet in addition to movement vocabulary, the audience receives further pedagogic instruction regarding krumping as a social and cultural form. Although many of the shots feature Henry in close-up, these are interspersed with mid-shots that reveal a stark, urban environment. In one instance, he dances by a fire escape staircase, and then on a metal walkway with a high-rise apartment building in the background. This firmly locates the vernacular form of krumping as a street dance practice that inscribes his body with working class values. The prosaic urban setting, brick walls, and fire escape suggest a life that lacks privilege, opulence, and wealth, and provides a compelling intertextual reference to the same discourses of poverty, deprivation, and marginalization evident in Rize. His acquisition of dancing knowledge has clearly not been attained through a private training school, nor does it take place within a venerated theatrical space. Instead, the camera shows quite literally how Henry learns and performs on the street.

Although So You Think You Can Dance has featured scenes of other dance genres on street locations, Henry's position as a "street dancer" continues through the entire audition scene, and the trope of a "raw street body" is reiterated and magnified through several close-ups of Henry as he talks and then dances. His mobile facial expressions are intense and unpredictable, while his voiceover states, "I'm aggressive, I'm what you'd call a gully, attitudish, grimy, gutter." 33 Yet unlike Rize, in which the krumpers detail their violent and unstable lives, So You Think You Can Dance simply hints at a disenfranchised existence without evidencing the veracity of Henry's reality. Nevertheless, his self-definition plays into a masculinized and racialized understanding of krumping, which follows from the framework of social and economic turbulence that underpins its evolution and has further circulated through Rize. Henry's black, male body can be read through critical race theorist David Theo Goldberg's articulation of an "Underclass." ${ }^{34}$ Henry's self-identification as "a gangsta", his embodied investment in this "aggressive" dance style, the inner-city street location that positions him outside the world of gainful employment, and his preoccupation with dance as a leisure form, all of which potentially prevents his entry into middle class society as a productive worker, clearly align him with this notion of a racial Underclass. 
So You Think You Can Dance constructs frameworks of value in response to different dancing bodies and, from Henry's pre-audition clip, we can see how it produces the krumping body as an aggressive, streetwise Other. Yet this racialized and masculinized body remains safely contained within the reality television format. Although some of the facial choreography in the pre-audition scene exposes a menacing, "grimy" self, we move on to see several head shots of Henry that serve to allay any sense of anxiety. Communications scholar Paul Frosh asserts that the head shot has dominated the history of television, and describes how the televisual closeup differs from the cinematic close-up in the way that television faces employ a mode of direct address..$^{35} \mathrm{He}$ conceives of this as a form of "parasocial interaction"36 between the "talking head" and the television spectator, which assumes a personalized one-toone relationship when "we are brought 'face-to-face' with our distant interlocutor." ${ }^{\text {"37 }}$

In the case of Henry, while the facial close-ups of his expressive dancing body are unsettling and intimidating, his talking head (as a familiar televisual device) serves to inform and reassure the spectator. Following the initial series of shots that portray his body within a dangerous, vernacular context, the scene cuts to an intimate facial close-up set within a quiet indoor location. He sits and calmly explains, "When krump came out, I got it right from the beginning." His benign demeanor, his gently raised eyebrows that signal a tentative explanation, the clarity of his language, and the passivity of his static body made safe within the indoor setting semiotically reposition him as secure and legible. This didactic strategy occurs again as his voiceover states, "I make stories with movements," and the clip cuts to another close-up of him on a residential street of town houses. This time, he slowly enacts his danced facial expressions and hand gestures, but each movement directly corresponds to a short phrase that he speaks: "Is that you over there?" and he thrusts his arm back and forth while staring intently ahead; "Boom, hold up," he looks sharply to the left while gesturing "halt" with his hand; "I'm gully," he frowns, clasping his fist to his chest; "I yell out," he cups his hands to his mouth; "Cause they hear me," he points to himself, nods twice, and so on. Thus his body is no longer threatening, and his face and gesture are no longer illegible, as he carefully decodes himself. The intimacy of this head shot gently instructs the individualized spectator as to how to read his body and, once again, we shift to a reassuring indoor close-up where he succinctly concludes, "To my eyes, I'm writing, with my body."

From this pre-audition scene, we observe how Henry's dancing body is "facialized" through Deleuze and Guattari's concept of the abstract machine. In the opening shot, his body initially appears free of this semiotic coding as his face seems to resist meaning through its strange contortions and ambiguous expressions. Indeed, Deleuze and Guattari assert that a tic can dismantle the organization of the face, and Henry's spasmodic facial and bodily gestures threaten to escape the disciplinary and authoritarian structures that "give the new semiotic system its means of imperialism." ${ }^{\prime 38}$ Yet this fleeting moment of uncertainty quickly dissolves as the facial machine begins to delimit Henry's dancing body through the rhetorical apparatus of 
voiceovers, head shots, and specified locations. The voiceovers contextualize and give meaning to krumping as a dance practice; the head shots reassure audiences that Henry's dangerous streetwise persona can be constrained through the salving conventions of reality television; the inner-city landscape classifies the dance and the dancer within a legible matrix of race, class, and gender; and the indoor close-ups safely position Henry as a static and meaningful interlocutor.

Notably, Deleuze and Guattari conceive the face as a racialized and gendered construction through their characterization of the "white wall" of the "White Man." ${ }^{39}$ In these terms, the facial machine determines normativity and allows for no intrusion, deviance or difference. Therefore the assemblage of voiceovers, headshots, and circumscribed locations ensure that Henry can only ever be read through the normalizing lens of a racial Other. As Rushton suggests, the overcoding of the abstract machine produces "faces" that are transparent and readable, and the excess of mediated faces that exist in print and on screen exemplify this semiotic operation. ${ }^{40}$ In the following section, we will see how Henry attempts to resist this facialization, but becomes ultimately incorporated into the discursive framework of the reality television machine.

\section{Meeting, Greeting, Dancing, and Resisting}

Throughout the studio audition scene, Henry, the three So You Think You Can Dance judges (Nigel Lythgoe, Mary Murphy, and Jason Gilikson), and the live studio audience are variously framed through close-ups, mid-shots, and full body shots ${ }^{41}$ For the purpose of this analysis, however, we want to call attention to a series of poignant facial close-ups to consider how Henry is aesthetically and performatively choreographed into this reality television show through Deleuze's notion of "affectimages." Deleuze observes that the face "gathers or expresses in a free way all kinds of tiny local movements which the rest of the body usually keeps hidden." ${ }^{\prime 42} \mathrm{He}$ further describes how the internal composition of each close-up in relation to other close-ups produces an "expressed complex entity" that comprises multiple singularities, some of which connect and some of which divide. ${ }^{43}$ We will therefore examine the choreographic interface - that is, the micro choreographies of facial interaction between Henry and the judges, and the extent to which they align with or divert from each other.

Deleuze asserts that affect can either exist as a reflective, immobile component or an expressive and intensive movement. We would argue that a predominantly "intensive face" emerges in the first part of the audition when Henry meets the judges and performs his dance; however, in the following section, a progressively "reflective face" comes into being as the judges offer their feedback. Deleuze envisages the "intensive face" as an expressive series of micro-movements that exceeds its surface and crosses boundaries. As Rushton observes, Deleuze prioritizes the "direction" rather than the "expression" of thoughts and feelings that mobilize the face, ${ }^{44}$ and this succession from one quality to another clearly presents itself in the first part of the 
audition. Indeed, the importance of editing comes into play as the temporal order of shots produces a dramatic narrative that underscores the sensationalism and competition typical of reality television shows. Here we see an unsettling trajectory of facial close-ups that evoke a mocking antagonism, an authoritarian appeal, outright denial, insistent classification, measured obstinacy, pure rejection, and a mobilized affirmation.

The audition scene begins as Henry enters the stage and, after a few polite greetings and introductions, judge Nigel Lythgoe inquires as to which dance style Henry prefers to perform. The camera cuts to a close-up as Henry provocatively responds, "You know that violent style you was talking about, krumping? That's what I do." In doing so, Henry stands confidently, frowning slightly, almost in a playful reprimand of Lythgoe's implicitly misguided interpretation of the dance. The shot swiftly cuts back to a close-up of Lythgoe who raises his palms in an open gesture of reasoned appeal, but accepts the categorization of krumping as violent, and offers a moral stance against this supposition. With a paternalistic raise of his eyebrows Lythgoe states, "It doesn't always have to be violent though!" Lythgoe continues with an assertion that krumper Russell Ferguson, the season six winner of So You Think You Can Dance, avoids its violent associations, at which point, the camera cuts to a closeup of Henry and, with a slight smile of disdain, he defiantly interjects, "I'm not Russell."

From this short exchange, through close-up to close-up, we witness the "pure power" of antagonism, reason, and denial. This succession of expressive qualities continues as Lythgoe locks Henry in a penetrating stare and provocatively questions, "So you're going to be violent?" Refusing to enter into this discourse of violence, Henry's face exudes calm, but his mouth obstinately states, "I'm gonna krump." Immediately aware of his vocal and facial resistance, all the three judges are caught in a mid-shot, their mouths locked in an open expression of astonishment as they emit the sound "whoa!" Although pantomimic in style, their faces clearly enunciate the marked shift from polite interactions to defiant provocations. Notably, the judges are further aligned through their white racial constitution, with Lythgoe from the United Kingdom, Murphy from the United States, and Gilikson from Australia, and their classbased privilege as successful professionals and high-profile celebrities from the entertainment industry. The camera again cuts to a close-up of Henry whose facial movement rapidly shifts across two distinct expressions, both of which refuse to be lured into Lythgoe's desire to position him as a violent, racial Other. First he stands, with gaze directed firmly away from the judges, his right palm raised as a sign of rejection, and his chin and bottom lip jutting outward to enhance his determined attitude; he then shifts slightly to raise both hands in the air, which may suggest a passive resignation, but his continued refusal to meet their gaze as he turns his head to face the opposite direction, strongly indicates a man who will not succumb to their taunting and who will not accept their racialized characterization of the dance.

On the one hand, the tension that unfolds as Henry and Lythgoe enter into a facial contestation over the associations of krumping with violence serves to engage 
television viewers in a compelling narrative drama. ${ }^{45}$ Yet performance scholar Megan Anne Todd argues that the presence of krumping on So You Think You Can Dance facilitates, "a platform and a visual space of dialogue for narratives beyond and critical to the cultural hegemony in dance aesthetics and society." 46 In Henry, and his interaction with the judges, we see the expressive lines of "faceicity" as suggested by Deleuze, as Henry intensely resists their complacent positioning of him as a dangerous Underclass. Rushton describes how the "intensive face" conveys feeling and experience; it acts as a dynamic and expressive force that breaks free from its outline through an autonomous series. ${ }^{47}$ Thus, while Lythgoe and his fellow judges seek to inscribe Henry with a rhetoric of racialized street violence, ideas already circulated through Rize, Henry's rapid succession of intense facial expressions of provocation, reprimand, disdain, denial, calm, determination, and rejection, and the facial responses of doubt, authority, and astonishment that this arouses in the judges, serves to negotiate and critique their normative claim.

Another brief exchange follows between Lythgoe and Henry regarding celebrity krumper Lil C, ${ }^{48}$ which alludes to the legacy of Rize and the concomitant popularization of krumping in music video. ${ }^{49}$ Henry responds through a stinging critique of the popular media's appropriation and commercialization of krumping, at which point Lythgoe invites him to dance. Throughout the dance, the style of filming shifts radically as the camera frames Henry's body almost entirely through full shots, with only occasional mid-shots and cut-away shots to the judges. In Deleuzian terms, this signals a change from the dislocated spatial and temporal coordinates of the close-up and its quality of pure affect, into an "action-image," which offers clear spatial and temporal determinates. ${ }^{50}$

Henry performs to a hip hop track with a driving beat, in what appears to be a spontaneous and improvised response to the music. In typical krumping style, he displays syncopated isolations, powerful arm gestures, and spectacular facial contortions, including one visually-arresting moment in which he mimes eating his hat and vomiting it back into his hand. Of note, however, are the strong emotions implicitly aroused through the dancing experience that prompt Henry to strip off his tshirt, drop down on all fours to pound the floor with his knuckles, and rip off his necklace. As the music fades and the dance comes to an end, clearly impassioned by the act of krumping, Henry repeatedly shouts "Yeah," which he underscores with clenched fists and flexed biceps. This apparent mobilization of passion and aggression is reflected in a shot of the cheering audience members, one of whom mirrors his vocal and physical affirmation. The extension, magnification, and fixing of this sheer physicality follows with a close-up of Henry who frowns intently, unable to take pleasure in the crowd's enthusiastic response. As Holmes suggests, the reality television close-up provides a, "superenhanced realism offering a perspective unavailable to the naked eye, which acts as a guarantor of authenticity and real emotion." ${ }^{151}$ Once again, Henry's self-affirmative passion presents itself as pure affect.

Within this first part of the audition, the exchange between Henry and the judges, followed by Henry's danced presentation, can be illuminated through 
Rushton's discussion of the "virtual" and the "actual" in relation to the face. ${ }^{52}$ Drawing on Deleuzian philosophy, ${ }^{53}$ Rushton asserts that while experiences are actual, the face presents a virtual expression of them. Ironically, the virtual constitutes the mode through which experiences are "actualized"; hence, the actual does not exist without the virtual. Consequently, this assumes that the virtual face potentially offers a myriad of endless possibilities; yet when the face comes into relation with another face, this delimits possibility to the finite. In reference to Delueze and Guattari, Rushton describes how this interaction "unleashes potential," and uses the example of how a "frightening face" that appears in a peaceful world offers the possibility of making the world "frightening." 54 During the pre-audition scene, Henry's face initially appears replete with possibility through its alienating, comical, and menacing contortions. Indeed, his racialized and sexualized body, as a streetwise, snarling Other, engenders the frightening face that potentially acts as a dangerous threat to the peaceful world of televised light entertainment. As Henry encounters the judges, however, the choreographic interplay of facial close-ups increasingly restricts this realm of possibility. While at first he seeks to resist this through the intensive facial encounters between himself and the judges, as well as through the mobilization of powerful dancing emotions actualized through his virtual face, as we see during the judges' feedback, his dancing body becomes increasingly circumscribed and "faceified" through the establishment and dominance of the "reflective face."

\section{Evaluation, Reflection, and Faceification}

The judges' feedback commences with Lythgoe, who now tries to position Henry within a lens of social and economic disenfranchisement. In a tight close-up, with gently knitted eyebrows and slight tilt forward, Lythgoe's face suggests concern and curiosity as he states, "I guess that it came out of frustration." As before, Henry attempts to resist through calling upon an alternative narrative of krumping. His head briefly shakes in denial and he glances above (almost as if invoking a higher presence) and firmly replies, "Not for me, I krump for my God, I krump for Christ." Notably, the links between krumping and spirituality also feature in Rize, but for the purposes of So You Think You Can Dance, it appears that the violence and oppression associated with krumping fuels the spectacle and drama of reality television, rather than the less inflammatory notions of morality and worship. Not satisfied, Lythgoe insists, "No, no, no, I'm talking about where it comes from," as he emphatically gestures to an imaginary object or being emitting from his body. Yet Henry remains resolute. His intensive face insists, "This is praise; this is a praise dance." For a fleeting moment, the camera cuts to a close-up of Lythoge whose face registers utter confusion, almost a "loss of face" with mouth agape and brow knotted, before returning to Henry's continued protestations. This approach clearly fails to position Henry according to Lythgoe's prescribed rendering of the disaffected krumping body, therefore following some awkward murmurings among the judges, attention swiftly moves to judge Mary 
Murphy and, from this point on, Henry's robust "faceicity" gradually disappears to be replaced by a "reflective face."

For Deleuze, the reflective face constitutes an immobile and receptive surface. ${ }^{55}$ It emerges as a "pure quality" common to several objects, thus creating a sense of unity. Unlike the intensive face, it lacks excitement, dynamism, and expression; rather it reflects, and thus collapses inwards. ${ }^{56}$ Murphy begins her critique by commanding, "Brian, could you put on your shirt please!" thus shifting the audience's attention toward his body. Captured in close-up, she turns to the audience and opens her mouth in mock outrage as if both shocked and overwhelmed by the allure of his body. As Henry compliantly puts on his t-shirt, a close-up follows of Murphy who elaborates to the audience, "Otherwise I won't be able to focus on my critique!" The shot cuts to the audience cheering and laughing, and then back to Henry who softly smiles as he straightens his shirt. The interfacial unity of Murphy's comedic response to the desirability of his body, the audience's jovial affirmation, and Henry's benign acquiescence collaboratively construct the pure quality of a reflective face. This facial exchange does not constitute an expressive series, but instead the unified and reflective iterations of humor simply collapse inwards.

Murphy's portrayal of Henry through the lens of a hyper-sexualized masculinity plays into a primitivist representation of the black male body that has operated since the beginning of film. Director, D.W. Griffith first presented the "Brutal Black Buck" in his controversial 1915 film, Birth of a Nation, which film historian Donald Bogle describes as African American men who are "oversexed and savage, violent and frenzied as they lust for white flesh. ${ }^{157}$ Goldberg asserts that the concept of the primitive emerged in the fifteenth century to describe an "origin," and which evolved in anthropology to refer to ancient or primeval societies. ${ }^{58}$ The term has subsequently developed to take on a racialized understanding that contrasts white European culture with non-Western cultures. From an evolutionist perspective, primitivism assumes that whereas European culture exhibits civilization, rationality, and order, the African body represents the uncivilized, promiscuous, and illogical Other. ${ }^{59}$ Consequently, the relations between Murphy's mockery, the audience laughter, and Henry's passive smile "reflect" a collusion through the consensual acceptance of his naked torso as a dangerous representation of the uncivilized and oversexualized primitive body. In Deleuzian terms, Henry's chest is faceified.

The critique continues as Murphy shifts from a disciplining of his body, to a castigation of his voice. Framed in a close-up, her face changes register to reflect a stern and serious attitude as she urges him to, "be careful when you knock fellow dancers who have come before you." For a brief moment, Henry resists through further explanation of his mission to reclaim krumping from the mainstream, but Murphy cuts this short. In close-up, devoid of emotion, with gritted teeth and a blank stare, she coldly states, "It's the tone of what you said ..." For a brief second, Henry looks awkward as doubt and confusion flash across his face, but he quickly returns to an immobile expression as he nods subserviently in compliance with her critique. This process of faceification continues as she brings her critique to an end. While Murphy 
complements Henry's krumping as "fantastic," and suggests that she would like to see him perform in the next round, her affirmative smile reflects upon and fixes his smile of pleasure in response to her praise.

The desire to delimit Henry's dancing body as unfinished and unrefined persists with judge Jason Gilikson's feedback. Once again, the shot cuts to a close-up that magnifies Gilikson's authority as a judge. After a brief comment regarding the entertainment value of the dancing, his gaze settles on Henry. His face adopts a slightly quizzical expression and his hands appear to grasp at an elusive truth as he states, "I think what it comes down to is I can't quite picture you doing a Broadway number, or a Viennese waltz, or a cha cha." As with Murphy, this commentary invokes a primitivist rhetoric in that the dances to which he refers are aligned with a white Euro-American aesthetic within the performance context of So You Think You Can Dance. Multiple dance scholars have traced the aesthetic and ideological shifts as vernacular dance practices are transmitted from African American to Euro-American bodies through a discursive framework of "savage to civilized."60 Indeed, Todd observes that So You Think You Can Dance perpetuates an "aesthetic prejudice toward the upward held torso and the unbroken line of classically 'Western' trained dancers." ${ }^{61}$ Thus located within a similar narrative of refinement, Gilikson fails to see how Henry's raw, violent, and vernacular body might be disciplined to the civilizing standards of competition ballroom and the Broadway stage.

Yet in spite of this moment of doubt, Gilikson continues with the suggestion that he would need to see Henry's capacity to achieve this in the next choreography round. In response, Henry nods, his arms held open, in a passive and reflective acceptance of all that Gilikson suggests. This compliance continues as the camera cuts to a close-up of Lythgoe. His face registers little emotion except for an extremely slight raise of the eyebrows and twitch at the corners of his mouth as he mischievously interjects, "I'm a 'yes' to choreography because I want to see if you can put your feet where your mouth is." In response to Lythgoe's humorous play on words and affirmation of his dancing ability, the shot lingers on a close-up of Henry's reflective face as he quickly winks in acknowledgement of the joke, and then smiles openly to the camera in recognition of his success. In return, the camera cuts back to a close-up of Lythgoe, also smiling as he bids goodbye to Henry. As an important point of closure, the relations between Henry and Lythgoe are no longer resistant, intensive, and combative, but compliant, reflective, and incorporated into the aesthetic and ideological framework of the reality television machine. In that brief wink, Henry accepts and colludes with the power structure that seeks to make his body legible to the television audience as a racialized, sexualized, and masculinized Other. Furthermore, he signals his willingness to disregard his vernacular krumping agenda to be re-trained in the choreography round according to the judges' Euro-American dance standards. 


\section{Facing the Facts}

In this article, we have departed from the genre of vernacular krumping to consider how its intense use of facial expression is re-choreographed for the purposes of documentary realism and reality television. We draw on Deleuzian philosophy to show how the facial machine of the reality show So You Think You Can Dance makes the krumping body meaningful through televisual devices, such as didactic voiceovers, circumscribed locations, "talking head" conventions, and the parasocial intimacy of the close-up. The spectator cannot assume that a priori meaning or subjectivity exists prior to facilialization; rather, dancer Brian Henry and his krumping practice are constructed through the semiotic regulation of the reality television closeup. Although his dancing body and use of facial expression initially convey instability and ambiguity, the reality television framework creates a pedagogy of krumping as a raw, unrefined streetdance, and performatively positions Henry as a potentially dangerous black Other. These ideas build on a narrative of krumping already in circulation through the film documentary Rize, although the viewer is offered no contextualizing information regarding Henry's personal background. Instead, the judges attempt to contain him through racist narratives of social and economic marginalization, a violent masculinity, an excessive sexuality, and an uncivilized and undisciplined body. Through an intensive series of pure power, however, the close-up magnifies Henry's refusal to be represented in these terms. His face and body commit to krumping's vernacular legacy and he exposes and resists the judges' aesthetic and ideological desire for him to conform to a Euro-American dance paradigm. Yet in order for Henry to progress in the competition, he needs to conform; therefore, his face changes to one of immobile compliance as he acquiesces to and mirrors the judges' feedback through the pure quality of his reflective face.

This entire exchange models a power framework of white, Western supremacy as the faces of the three white judges delimit Henry's African American body so that it can only be known through the close-up lens of a racialized, sexualized, and masculinized Other. In reference to faciality, Deleuze and Guattari suggest, "Racism never detects the particles of the other; it propagates waves of sameness until those who resist identification have been wiped out." ${ }^{62}$ Notably, although Henry successfully passes this audition, he does not make it beyond the choreography round. On one hand, this could be read as his failure to conform to the Euro-American ideal; on the other, his elimination attests to his political commitment to vernacular krumping and continued resistance to the normalizing intent of the reality television machine.

Although our analysis only focuses on a six-minute clip, the concept of "facial choreography" and the "choreographic interface" can be applied to other screendance genres as well. The framing of the face through the close-up and the temporal organization of those shots produces a clear sense of facial composition, and the interactions between screen faces, the implied positioning of the spectator within those exchanges, and the intertextual references to other screen faces create a choreographic interface, which forms a rich site of meaning-production. This choreographic exchange provides an analytical framework to expose the pedagogic, 
aesthetic, and performative values that underpin reality television dance shows, and may be applied to other dance genres within the reality television format or within screendance generally. While the choreographic interface clearly seeks to delimit our knowledge of the dancing body according to social and cultural norms, it also facilitates an "actualized" site of expressive facial interactions through which values can be constructed, resisted, and negotiated.

\section{Notes}

1. Dan McNeill, The Face (Boston: Little Brown, 1998).

2. Paul Coates, Screening the Face (Basingstoke: Palgrave, 2012).

3. So You Think You Can Dance premiered in 2005 on Fox television and is now in its 11 th season. Its contestants are required to perform dance routines in a variety of styles within the format of a knock-out competition.

4. "SYTYCD USA: Brian Henry auditions (krump)," BboyRisky1, YouTube, 2011.

5. See Phillip Auslander, "Musical Personae," The Drama Review 50, no. 1 (2006): 100119; Sherril Dodds, Dancing on the Canon: Embodiments of Value in Popular Dance. (Basingstoke: Palgrave, 2011); Abigail Feder, "'A Radiant Smile for the Lovely Lady': Overdetermined Femininity in 'Ladies' Figure Skating," The Drama Review 38, no. 1 (1994): 62-78; Brenda Foley, Undressed for Success: Beauty Contestants and Exotic Dancers as Merchants of Morality (Basingstoke: Palgrave Macmillan, 2005); and Katherine Liepe-Levinson, Strip-Show: Performances of Gender and Desire (London: Routledge, 2002).

6. Erin Brannigan, Dancefilm: Choreography and the Moving Image (New York: Oxford University Press, 2011).

7. Brannigan, Dancefilm, 44.

8. Although film and television employ different modes of production, dissemination and reception, Frosh (2009) observes how the notion of the small box-shaped television set has been replaced by large, high definition, flat screen televisions, which Rodan $(2009,367)$ notes can create "isolated cinematic spaces."

9. Gilles Deleuze, Cinema 1: The Movement Image, trans. Hugh Tomlinson and Barbara Habberjam (Minneapolis: University of Minnesota Press, 1986); Gilles Deleuze and Felix Guattari, $A$ Thousand Plateaus: Capitalism and Schizophrenia (Minneapolis: University of Minnesota Press, 1987).

10. Deleuze and Guattari, $A$ Thousand Plateaus. 
11. Ibid., 168, emphasis original.

12. André Lepecki, "Machines, Dances, Neurons: Towards an Ethics of Dance," The Drama Review 51, no. 3 (2007): 119-123.

13. Ibid., 179-80.

14. Deleuze, Cinema 1. Although Deleuze focuses on film, as with the work of Brannigan, these ideas can be extended to television through its capacity to frame and edit two-dimensional images.

15. Ibid., 59, emphasis original.

16. Ibid., 66.

17. Richard Rushton, "What Can a Face Do?: On Deleuze and Faces," Cultural Critique 51 (2002): 219-237.

18. Christina Zanfanga, "The Multiringed Kosmos of Krumping: Hip-Hop Dance at the Intersections of Battle, Media and Spirit," in Ballroom, Boogie, Shimmy Sham Shake: A Social and Popular Dance Reader, ed. Julie Malnig (Urbana and Chicago: University of Illinois Press, 2009), 337-353.

19. Ibid.

20. Ibid.

21. Ibid., 342.

22. Rize, Dir. David LaChapelle (Lions Gate, 2005).

23. Chris Ayres, "You Don't Want to Face the Gunfire of Compton? Go and Watch the Movie," The Times, June 28, 2005, 17.

24. Belinda Smaill, "Injured Identities: Pain, Politics and Documentary," Studies in Documentary Film 1, no. 2 (2007): 160.

25. Nicole M. Monteiro and Diana J. Wall, "African Dance as Healing Modality Throughout the Diaspora: The Use of Ritual and Movement to Work Through Trauma," The Journal of Pan African Studies 4, no. 6 (2011): 234-252.

26. Ibid., 247; Zanfanga, "The Multiringed Kosmos of Krumping," 345.

27. After the first round of open auditions, the judges select promising dancers to perform in the choreography round, in which they must demonstrate competence in a variety of choreographed routines.

28. Kate Elswit, "So You Think You Can Dance Does Dance Studies," The Drama Review 56, no. 1 (2012): 136.

29. Deleuze, Cinema 1. 
30. Deleuze and Guattari, $A$ Thousand Plateaus.

31. Elswit, "So You Think You Can Dance"; Guy Redden, "Making Over the Talent Show," Exposing Lifestyle Television: The Big Reveal, ed. Gareth Palmer (Burlington: Ashgate, 2008), 129-143.

32. Su Holmes, "'Reality goes pop!': Reality TV, Popular Music, and Narratives of Stardom in Pop Idol," Television \& New Media 5, no. 2 (2004): 161.

33. "Gully" can be defined as from the street, the gutter and/or a "gangsta" (www.urbandictionary.com, accessed April 4, 2013).

34. David Theo Goldberg, "Racial Knowledge," Theories of Race and Racism, ed. Les Back and John Solomos (London: Routledge, 2000), 154-180. Goldberg describes the Underclass as a racialized construct, which pathologizes the black community as an "undeserving poor." Read within the spatial representation of an inner-city landscape, the Underclass refers to those unmotivated to work, mothers on benefit, street criminals, and urban gangs.

35. Paul Frosh, "The Face of Television," Annals of the American Academy of Political and Social Science 625 (2009): 87-102.

36. Ibid., 90.

37. Ibid., 91.

38. Deleuze and Guattari, $A$ Thousand Plateaus, 181.

39. Ibid., 176.

40. Rushton, "What Can a Face Do?"

41. Judge Nigel Lythgoe is a former dancer who has produced multiple reality television shows, including So You Think You Can Dance, Popstars, Pop Idol, and American Idol(www.fox.com/dance/bios/hosts-judges/nigel-lythgoe;

www.imdb.com/name/nm0529328/3); Mary Murphy was a former championship ballroom dancer (www.fox.com/dance/bios/hosts-judges/mary-murphy); and Jason Gilikson is also a former ballroom dancer and award winning choreographer (www.jasongilkison.com).

42. Ibid., 87-88.

43. Deleuze, Cinema 1, 104.

44. Rushton, "What Can a Face Do?," 228-9.

45. See Elswit, "So You Think You Can Dance Does Dance Studies," for further discussion of the narrative dramas that underpin reality television dance contests. 
46. Megan Anne Todd, "Aesthetic Foundations and Activist Strategies of Intervention in Rickerby Hinds' Buckworld One," The Journal of Pan African Studies 4 no. 6 (2011): 151.

47. Rushton, "What Can a Face Do?"

48. Lil C starred in Rize and featured as a guest judge on So You Think You Can Dance. 49. See for example Hung Up by Madonna, Hey Mama by Black Eyed Peas and I'm Really Hot by Missy Elliott.

50. Deleuze, Cinema 1.

51. Holmes, "Reality Goes Pop!", 161.

52. Deleuze, Cinema 1.

53. Rushton calls upon additional material here from Deleuze's, Difference and Repetition and Deleuze and Guattari's, What is Philosophy?

54. Rushton, "What Can a Face Do?," 228.

55. Deleuze, Cinema 1.

56. Rushton, "What Can a Face Do?"

57. Donald Bogle, Toms, Coons, Mulattoes, Mammies and Bucks: An Interpretive History of Blacks in American Films, 4th ed. (New York: Continuum, 2001).

58. Goldberg, "Racial Knowledge."

59. Goldberg, "Racial Knowledge," and Nadine George Graves "'Just Like Being at the Zoo': Primitivity and Ragtime Dance," in Ballroom, Boogie, Shimmy Sham Shake: A Social and Popular Dance Reader, ed. Julie Malnig (Urbana and Chicago: University of Illinois Press, 2009), 55-71.

60. See Susan C. Cook "Talking Machines, Dancing Bodies: Marketing Recorded Dance Music Before World War 1," in Bodies of Sound: Issues Across Popular Music and Dance, ed. Sherril Dodds and Susan C. Cook (Farnham: Ashgate, 2012), 149-162; Jane Desmond, "Embodying Difference: Issues in Dance and Cultural Studies," in Meaning in Motion: New Cultural Studies of Dance, ed. Jane Desmond (Durham and London: Duke University Press, 1997), 29-54; George Graves, "Just Like Being at the Zoo"; Juliet McMains, Glamour Addiction: Inside the American Ballroom Industry (Middletown, Connecticut: Wesleyan University Press, 2006).

61. Todd, "Aesthetic Foundations \& Activist Strategies," 151.

62. Deleuze and Guattari, $A$ Thousand Plateaus, 178. 


\section{References}

Auslander, Phillip. “Musical Personae.” The Drama Review 50, no. 1 (2006): 100-119.

Ayres, Chris. "You Don't Want to Face the Gunfire of Compton? Go and Watch the Movie." The Times, June 28, 2005: 17.

"Biography: Jason Gilikson." Ten2 Productions. Accessed April 3, 2013. http://www.jasongilkison.com/biography-latin-dance-choreography/.

Brannigan, Erin. Dancefilm: Choreography and the Moving Image. New York: Oxford University Press, 2011.

Bogle, Donald. Toms, Coons, Mulattoes, Mammies and Bucks: An Interpretive History of Blacks in American Films. $4^{\text {th }}$ ed. New York: Continuum, 2001.

Coates, Paul. Screening the Face. Basingstoke: Palgrave, 2012.

Cook, Susan C. "Talking Machines, Dancing Bodies: Marketing Recorded Dance Music Before World War 1." In Bodies of Sound: Conversations Across Popular Music and Dance, edited by Sherril Dodds and Susan C. Cook, 149-162. Farnham: Ashgate, 2012.

Deleuze, Gilles. Cinema 1: The Movement Image. Translated by Tomlinson, Hugh and Habberjam, Barbara. Minneapolis: University of Minnesota Press, 1986.

Deleuze, Gilles and Guattari, Felix. A Thousand Plateaus: Capitalism and Schizophrenia. Minneapolis: University of Minnesota Press, 1987.

Desmond, Jane. "Embodying Difference: Issues in Dance and Cultural Studies."

Meaning in Motion: New Cultural Studies of Dance, edited by Jane Desmond, 29-54.

Durham and London: Duke University Press, 1997.

Dodds, Sherril. Dancing on the Canon: Embodiments of Value in Popular Dance.

Basingstoke: Palgrave, 2011.

Elswit, Kate. "So You Think You Can Dance Does Dance Studies." The Drama Review 56, no. 1 (2012): 133-142.

Feder, Abigail. "'A Radiant Smile for the Lovely Lady': Overdetermined Femininity in 'Ladies' Figure Skating." The Drama Review 38, no. 1 (1994): 62-78.

Foley, Brenda. Undressed for Success: Beauty Contestants and Exotic Dancers as Merchants of Morality. Basingstoke: Palgrave Macmillan, 2005.

Frosh, Paul. "The Face of Television." Annals of the American Academy of Political and Social Science 625 (2009): 87-102.

George Graves, Nadine. "'Just Like Being at the Zoo': Primitivity and Ragtime Dance." In 
Ballroom, Boogie, Shimmy Sham, Shake: A Social and Popular Dance Reader, edited by Julie Malnig, 55-71. Urbana and Chicago: University of Illinois Press, 2009.

Goldberg, David Theo. "Racial Knowledge." In Theories of Race and Racism, edited by Les Back and John Solomos, 154-180. London: Routledge, 2000.

Holmes, Su. "'Reality goes pop!': Reality TV, Popular Music, and Narratives of Stardom in Pop Idol." Television \& New Media 5, no. 2 (2004): 147-172.

"Gully." Urbandictionary.com. Accessed April 4, 2013.

http://www.urbandictionary.com/define.php?term=gully.

"Judges: Mary Murphy." So You Think You Can Dance. Accessed April 3, 2013.

http://www.fox.com/dance/bios/hosts-judges/mary-murphy.

"Judges: Nigel Lythgoe." So You Think You Can Dance. Accessed April 3, 2013.http://www.fox.com/dance/bios/hosts-judges/nigel-lythgoe/.

Lepecki, André. "Machines, Dances, Neurons: Towards an Ethics of Dance." The Drama Review51, no. 3 (2007): 119-123.

Liepe-Levinson, Katherine. Strip-Show: Performances of Gender and Desire. London:

Routledge, 2002.

McMains, Juliet. Glamour Addiction: Inside the American Ballroom Industry.

Middletown, Connecticut: Wesleyan University Press, 2006.

McNeill, Dan. The Face. Boston: Little Brown, 1998.

Monteiro, Nicole M. and Diana J. Wall. "African Dance as Healing Modality Throughout the Diaspora: The Use of Ritual and Movement to Work Through Trauma." The Journal of Pan African Studies 4, no. 6 (2011): 234-252.

"Nigel Lythgoe." Internet Movie Database. Accessed 3 April 2013.

http://www.imdb.com/name/nm0529328/3.

Palmer, Gareth. "'The New You' Class and Transformation in Lifestyle Television." In Understanding Reality Television, edited by Su Holmes and Deborah Jermyn, 173-190. London: Routledge, 2004.

Redden, Guy. "Making Over the Talent Show." In Exposing Lifestyle Television: The Big Reveal, edited by Gareth Palmer, 129-143. Burlington: Ashgate, 2008.

Rodan, Debbie. "Large, Sleek, Slim, Stylish Flat Screens: Privatized space and the Televisual Experience." Continuum: Journal of Media \& Cultural Studies 23, no. 3 (2009): 367-382.

Rushton, Richard. "What Can a Face Do?: On Deleuze and Faces." Cultural Critique 51 (2002): 219-237. 
Smaill, Belinda. "Injured Identities: Pain, Politics and Documentary." Studies in Documentary Film 1, no. 2 (2007): 151-163.

Todd, Megan Anne. "Aesthetic Foundations and Activist Strategies of Intervention in Rickerby Hinds' Buckworld One." The Journal of Pan African Studies 4, no. 6 (2011): 148-170.

Weisbrod, Alexis. "Competition Dance: Redefining Dance in the United States." Unpublished PhD Diss., University of California Riverside, 2010.

Zanfanga, Christina. "The Multiringed Kosmos of Krumping: Hip-Hop Dance at the Intersections of Battle, Media and Spirit." In Ballroom, Boogie, Shimmy Sham Shake: A Social and Popular Dance Reader, edited by Julie Malnig, 337-353. Urbana and Chicago: University of Illinois Press, 2009.

\section{Media}

Rize. Dir. David LaChapelle. Lions Gate 2005. Film.

"SYTYCD USA: Brian Henry auditions (krump)." BboyRisky1. 2011. YouTube. 